\title{
ВИКЛАДАННЯ ЗАГАЛЬНОТЕХНІЧНИХ ДИСЦИПЛІН \\ В УМОВАХ ЗМІШАНОГО НАВЧАННЯ В ЗАКЛАДАХ ВИЩОЇ ОСВІТИ
}

\section{Доценко Н. А.}

\section{ВСТУП}

При вивченні сучасними інженерами загальнотехнічних дисциплін виникає необхідність перетворення системи підготовки, постає потреба в нових підходах, які пов'язані 3 міждисциплінарністю навчання та використанням сучасних технологій. Такий рівень підготовки майбутніх інженерів забезпечується в умовах інформаційно-освітнього середовища закладу вищої освіти. Технологія змішаного навчання 3 використанням інформаційно-освітнього середовища закладу вищої освіти підтримує постійний доступ до процесу навчання, може бути здійсненим на таких пристроях, як телефон, ноутбук або планшет. Використання аудіовізуальних матеріалів збільшується в геометричній прогресії під час навчання.

Загальнотехнічні дисципліни сприяють розвитку базових та фахових професійних компетентностей майбутнього фахівця, допомагають йому глибше розуміти застосування законів природознавства в техніці й технології виробництва. Але інформатизація навчання, технології дистанційного та змішаного навчання вимагають належного рівня підготовки освітнього контенту. Виникає потреба в удосконаленні методик інтерактивного практичного навчання при підготовці фахівців у закладах вищої освіти ${ }^{1}$. Так, питання щодо розроблення технології викладання загальнотехнічних дисциплін у закладах вищої освіти в умовах змішаного навчання набуває актуальності в теперішніх умовах.

\section{1. Технологія викладання загальнотехнічних дисциплін}

\section{в умовах інформаційно-освітнього середовища}

У 2018 році акцент робиться на різних аспектах, починаючи від того, як здобувачі вищої освіти отримують доступ до змісту, як визначається ідея «навчального плану». Такі технології, як планшетні персональні комп'ютери, програми та доступ до інтернету, полегшують

${ }^{1}$ Силадій I. М. Демократизація освіти як свобода вибору моделі освітнього процесу. Національний педагогічний університет імені М.П. Драгоманова. Філософія. № 38(51). 2017. С. 235-241. 
перехід до навчання в умовах інформаційно-освітнього середовища, але занурення в навчальне середовище виходить за межі інструментів для навчання ${ }^{2}$.

Термін «змішане навчання» (в англомовній літературі - "blended", "hybrid learning") має різні визначення в літературі. Загалом, це поєднання офлайн- (або особисто, «на місці») та онлайн-навчання в різних пропорціях ${ }^{3}$.

Науково-методичне забезпечення змішаного навчання включає:

- методичні (теоретичні та практичні) рекомендації щодо розроблення та використання педагогічно-психологічних та інформаційно-комунікаційних технологій змішаного навчання;

- критерії, засоби й системи контролю якості змішаного навчання;

- змістовне, дидактичне та методичне наповнення дистанційних курсів.

Розвиток сучасних технологій висуває підвищені вимоги до майбутнього інженера, роботодавці зацікавлені у висококваліфікованих кадрах, для яких властива професійна мобільність та належний рівень володіння фаховими компетентностями ${ }^{4}$.

Загальнотехнічні дисципліни:

- сприяють політехнізації навчання;

- забезпечують підготовку до вивчення фахових дисциплін;

- допомагають глибше розуміти закони природознавства та їх застосування в техніці;

- роблять внесок у формування технічного світогляду;

- розвивають інженерну думку.

До загальнотехнічних дисциплін належить механіка матеріалів і конструкцій, теорія механізмів і машин, нарисна геометрія, інженерна та комп'ютерна графіка, деталі машин, теоретична механіка, взаємозамінність, стандартизація та технічні вимірювання тощо.

Розглянемо реалізацію технології підготовки майбутніх інженерів із загальнотехнічних дисциплін в умовах змішаного навчання з використанням інформаційно-освітнього середовища закладів вищої освіти (рис. 1).

${ }^{2}$ Decree of the President of Ukraine. 2013.

3 Кухаренко В., Березенська С., Бугайчук К., Олійник Н., Олійник Т., Рибалко О., Столяревська А. Теорія і практика змішаного навчання: монографія. Харків : Міськдрук, НТУ «ХПІ». 2016. С. 286.

${ }_{4}$ Agricultural engineers. 2020. URL: https://collegegrad.com/careers/agriculturalengineers. 


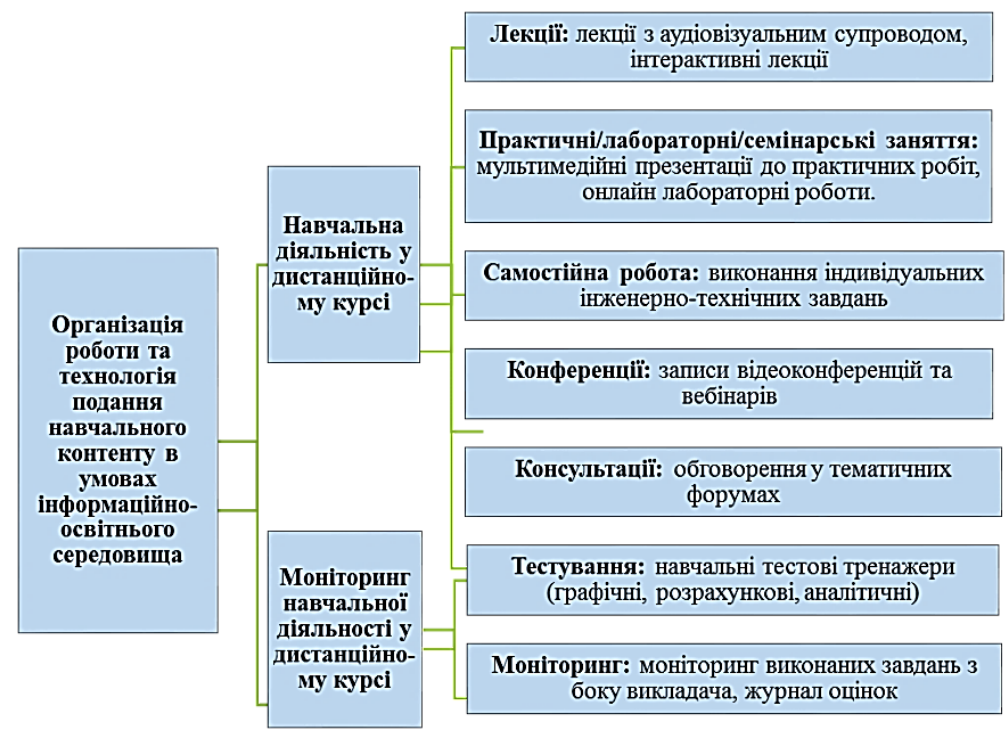

Рис. 1. Технологія підготовки майбутніх інженерів із загальнотехнічних дисциплін в умовах змішаного навчання із використанням інформаційно-освітнього середовища закладів вищої освіти

Розглянемо основні властивості інструментів навчання в умовах інформаційно-освітнього середовища для вивчення загальнотехнічних дисциплін ${ }^{5}$.

Завдання: мультимедійні презентації до практичних робіт (в основу покладено вид навчальних занять практичного характеру, спрямованих на поглиблення, розширення, деталізацію й закріплення теоретичного матеріалу); практичні роботи онлайн (здобувач вищої освіти набуває навичок у роботі 3 устаткуванням, обладнанням, методикою експериментальних досліджень) ${ }^{6}$.

Урок (лекиія): лекція 3 аудіовізуальним супроводом (забезпечує науковий виклад великого обсягу чітко систематизованої й концентрованої, методично й грамотно опрацьованої сучасної наукової інформації, встановлення контакту 3 аудиторією та забезпечення ефективного зворотного зв'язку, монолог викладача супроводжується слайдами, відеофрагментами, завданнями);

${ }^{5}$ Benson R., Brack C. Online Learning and Assessment in Higher Education. A Planning Guide. Elsevier. 2010

${ }^{6}$ Cristopner P. 7 Best Praktikes For Developing Personalized elearning Courses. 2016. URL: https://elearningindustry.com/best-practices-developing-personalizedelearning-courses. (дата звернення: 03.05.2018). 
інтерактивна лекція (включає не лише мультимедійні властивості, а й компоненти інтерактивності) ${ }^{7}$.

Tecm: навчальний тестовий тренажер - програма, призначена для самостійного вивчення (або повторення) з одночасним контролем знань із певної теми, представляє комплекс, систему моделювання, комп'ютерні та фізичні моделі, спеціальні методики, які створюються для того, щоб підготувати особистість до ухвалення якісних і швидких рішень ${ }^{8}$.

Інтерактивний контент - це будь-який контент (відео, графічний, аудіо), що передбачає активну участь здобувачів вищої освіти та контроль знань, обов'язковою є наявність зворотного зв'язку'.

Опитування - інструмент навчання, який може проводитись для здобувачів вищої освіти, за його результатами відбувається вдосконалення структури курсу.

Чат та форум - інструменти, за допомогою яких викладач підтримує зв'язок зі здобувачами, проводить консультування.

Обов'язковим $є$ моніторинг підготовки майбутніх інженерів в умовах змішаного навчання та дослідження ступеня набуття фахових компетентностей $^{10}$. Методику навчання загальнотехнічних дисциплін в умовах змішаного навчання представлено нижче (рис. 2).

Суттю навчальних посібників для навчання майбутніх інженерів загальнотехнічних дисциплін в умовах змішаного навчання 3 використанням інформаційно-освітнього середовища $\epsilon$ те, що за ними можна працювати як самостійно вдома, так і в аудиторії. Для роботи в аудиторії представлено теоретичний матеріал, прототипи практичних робіт та питання до заліків та екзаменів. В умовах інформаційноосвітнього середовища представлено широкий спектр інструментів, а саме: мультимедійні презентації до практичних робіт, інтерактивні лабораторні роботи, лекції з аудіовізуальним супроводом, навчальні комп'ютерні інтерактивні тренажери, онлайн-глосарії, форуми, записи вебінарів тощо ${ }^{11}$.

${ }^{7}$ Wang C.-H., Shannon D. M., Ross M. E. Students' characteristics, self-regulated learning, technology self-efficacy, and course outcomes in online learning. Distance Education. № 34. 2013. C. 302-323.

${ }^{8}$ Андрощук I. M. E-learning як ефективна форма самоуправління професійним розвитком викладачів кафедр менеджменту польських закладів вищої освіти. Нова педагогічна думка: науково-методичний журнал. 2018. С. 3-6.

${ }^{9}$ Pandey A. 10 Mobile Learning Trends For 2018. Eidesign. 2018.

10 Ткачук C.I. Компетентнісний підхід як основа професійної підготовки інженерів-педагогів харчового профілю у вищих педагогічних навчальних закладах. Сучасні інформачійні технології та інновачійні методики навчання в підготовиі фахівців: методологія, теорія, досвід, проблеми. № 50. 2019. С. 384-387.

${ }^{11}$ Шполянская И., Мисиченко Н. Анализ требований работодателей в системе поддержки трудоустройства выпускников ВУЗа. Вестник Государственного ростовского экономического университета «РИНХ». 2009. С. 330-337. 


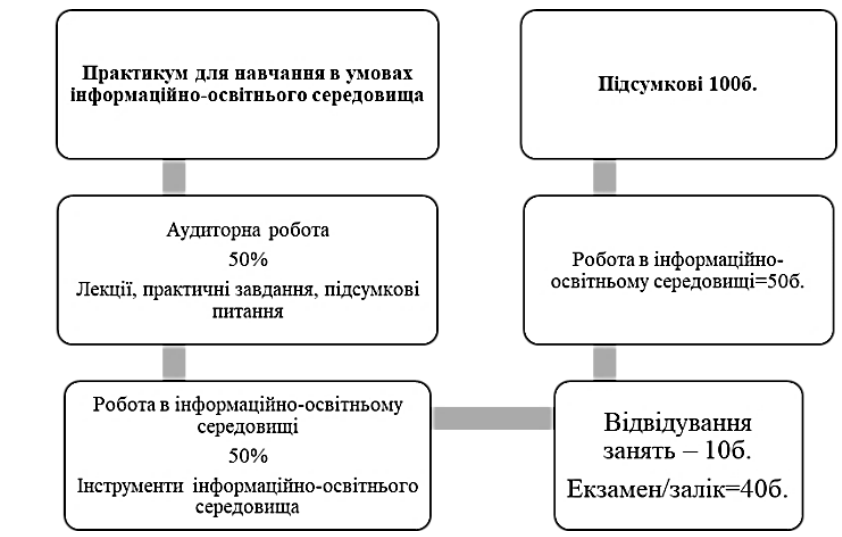

\section{Рис. 2. Методика навчання майбутніх інженерів загальнотехнічних дисциплін в умовах змішаного навчання}

Схема навчання майбутніх інженерів загальнотехнічних дисциплін в умовах змішаного навчання здійснюється так: здобувачі вищої освіти попередньо ознайомлюються 3 теоретичним матеріалом. Потім в аудиторії вони починають практичне виконання завдань, які представлені в навчальному посібнику за допомогою QR-кодів. Здобувачі вищої освіти за допомогою додатків для зчитування QR-кодів переходять на відповідний розділ курсу та приступають до виконання завдань на персональному комп'ютері або мобільному телефоні, що представлені за допомогою інтерактивних електронних інструментів, а саме: мультимедійні презентації до практичних робіт, інтерактивні лабораторні роботи, лекції з аудіовізуальним супроводом, навчальні комп'ютерні інтерактивні тренажери тощо ${ }^{12}$. Виконавши 3 мобільного телефону завдання, інформаційно-освітнє середовище формує оцінку для здобувачів вищої освіти та статистичні показники щодо виконання завдання для викладача. Таким чином, для майбутніх інженерів формується рейтинг під час навчання в умовах інформаційно-освітнього середовища, який впливає на підсумкову оцінку. В інформаційно-освітньому середовищі здобувачі вищої освіти можуть навчатися як в аудиторії, так і виконувати роботу самостійно. Викладач контролює час проходження певних завдань в інформаційно-

12 Доценко Н.А. Набуття компетенцій в умовах інформаційно-освітнього середовища: організаційний аспект. Освіта $i$ наука в умовах глобальних трансформаиій: матеріали II Всеукраӥнської наукової конференції. Дніпро, 2018. 
освітньому середовищі та встановлює обмеження в часі та в кількості спроб ${ }^{13}$.

Отже, реалізація технології вивчення загальнотехнічних дисциплін в умовах змішаного навчання закладів вищої освіти передбачає інтеграцію навчання в аудиторії та віртуальному єдиному просторі. Для підготовки майбутніх інженерів доцільно формувати посібники для вивчення кожної дисципліни в умовах інформаційно-освітнього середовища. Такі посібники є допомогою в опануванні як теоретичного матеріалу, так i навігації курсом, де представлені інтерактивні електронні навчальні інструменти для виконання завдань в умовах інформаційно-освітнього середовища. балів, отриманих в аудиторії, та рейтингу здобувачів вищої освіти під час навчання в умовах інформаційно-освітнього середовища. Окреслений підхід здатен допомогти в якісному опануванні навчального контенту за обраним фахом. Використання інтерактивних аудіовізуальних засобів дозволяє наочно ознайомитися 3 теоретичними, практичними та експериментальними положеннями, що $є$ важливими для вивчення загальнотехнічних дисциплін майбутніми інженерами ${ }^{14}$.

\section{2. Створення лекційного контенту для вивчення}

\section{загальнотехнічних дисциплін в умовах змішаного навчання}

Принцип інтеграції допоміжних ресурсів та інформаційноосвітнього середовища полягає в тому, що відеоконтент, презентативний контент та текстовий контент із великою кількістю формул, таблиць або графіків зберігається в умовах сучасних глобальних ресурсів. А в інформаційно-освітньому середовищі за допомогою панелі редагування можна вставити лише код упровадження, щоб інформація була представлена у відкритій формі. Тоді в умовах інформаційно-освітнього середовища автоматично ведеться моніторинг роботи здобувача вищої освіти 3 відповідним контентом. Розглянемо методику використання лекційних матеріалів 3 аудіовізуальним супроводом для вивчення загальнотехнічних дисциплін в умовах інформаційно-освітнього середовища. Теоретичний матеріал доцільно розміщувати у вигляді тексту 3 аудіовізуальним супроводом. Ступінь сприйняття навчального матеріалу перевіряється систематично за допомогою контрольних онлайн-питань. Без

13 Витвицкая С. Структура и критерии готовности магистров. Вектор науки Тольяттинского Государственного Университета. Серия: Педагогика, психология. № 2 (13). 2013. С. 59-63.

14 Пастухов В.И. Современные требования к квалификации инженера сельскохозяйственного производства. Вісник Украӥнського відділення Міжнародної академї аграрної освіти. Запоріжжя, 2013. 
правильної відповіді не можна перейти до наступного пункту інтерактивної лекції.

Застосування зображень, презентацій 3 аудіосупроводом, відеофрагментів покращує якість сприйняття навчального матеріалу. Викладений матеріал майбутній інженер може повторювати стільки, скільки необхідно для засвоювання. Такий вид інтерактивної лекції не обмежений одним питанням і можливий перехід на попередню або наступну сторінку, тобто здобувач вищої освіти сам регулює час, який він витрачає на засвоєння матеріалу, адже це залежить від індивідуальних потреб.

Залежно від вибору відповіді і від того, як викладач подає лекцію, здобувачі вищої освіти можуть перейти на наступну сторінку, повернутися на попередню сторінку інтерактивної лекції або перенаправлятися зовсім іншим шляхом (наприклад за допомогою QR-коду) (рис. 3).

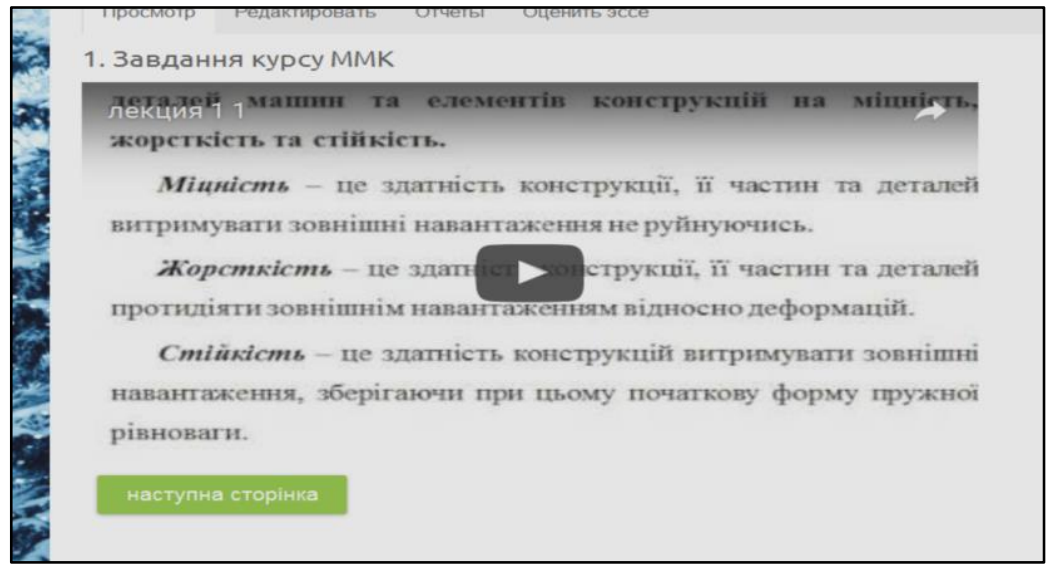

Рис. 3. Подання навчального матеріалу з дисципліни «Механіка матеріалів і конструкцій» у вигляді відеолекцій

Також, як уже зазначалось, після кожної інтерактивної лекції здобувач вищої освіти проходить контроль у вигляді інтерактивного питання стосовно пройденого матеріалу. Зазначимо, що в межах подання тексту важливо мати цікавий заголовок. Необхідно уникати в заголовках невизначеності, невиразності й надмірної складності. Підготовка електронного тексту інтерактивної лекції має враховувати такі принципи:

- кількість навчального матеріалу на екрані має бути невеликою;

- подання матеріалу в інтерактивній лекції має супроводжуватись питанням для перевірки; 
- кольорова гама та інші засоби подання матеріалу в межах інформаційно-освітнього середовища мають забезпечувати естетичний зовнішній вигляд.

У верхній частині екрана потрібно вказати назву лекції. Бічна панель навігації дозволяє перейти до інших частин курсу (рис. 4).

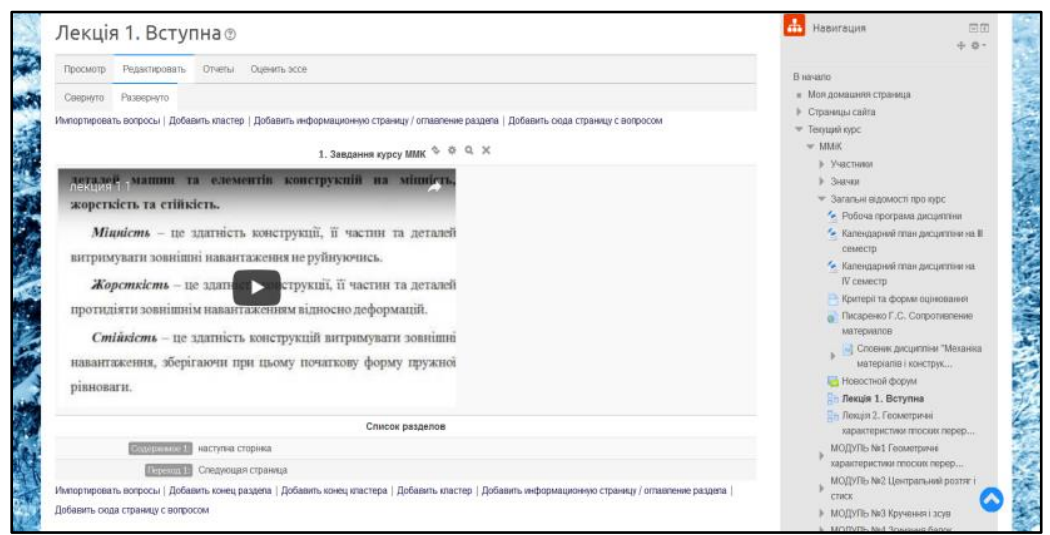

Рис. 4. Фрагмент лекції з аудіовізуальним супроводом та навігація курсом на прикладі дисципліни «Механіка матеріалів і конструкцій»

Web-сторінка - найбільш популярний елемент, який дозволяє створювати гіпертекстові сторінки 3 навчальним контентом. Цей елемент можна використовувати для розміщення теоретичного навчального матеріалу у вигляді текстової інформації з використанням рисунків, посилань, таблиць, графічних об'єктів, звуку, анімації тощо. Але особливістю цього елементу є те, що в ньому відсутній зворотний зв'язок, тобто цей елемент призначений лише для представлення навчального матеріалу. Використання Web-сторінки дозволяе використовувати динамічні інтерактивні елементи, що сприяє активізації навчання, підвищенню рівня формування професійної компетентності. Web-сторінка може мати посилання на зовнішні гіпертекстові сторінки 3 інтернету, що сприяє під час вивчення матеріалу використанню додаткових джерел інформації з інтернету. При проектуванні навчального контенту для дисциплін в інформаційно-освітньому середовищі цей елемент використовувався для розміщення модульних оглядових лекцій. Представлено приклад створення вебсторінки з використанням відеофрагмента. 


\section{3. Створення навчальних комп'ютерних інтерактивних тренажерів для вивчення}

\section{загальнотехнічних дисциплін в умовах змішаного навчання}

В основу навчальних комп'ютерних інтерактивних тренажерів в умовах інформаційно-освітнього середовища покладено використання певного тренувального завдання. Його суть полягає в тому, що за короткий проміжок часу, використовуючи різні прийоми роботи 3 навчальним матеріалом, можна швидше навчити здобувачів вищої освіти інженерних спеціальностей його запам'ятовувати. При створенні навчальних комп'ютерних інтерактивних тренажерів для вивчення загальнотехнічних дисциплін в умовах інформаційно-освітнього середовища необхідно визначити такі етапи ${ }^{15}$ :

1) знайомство 3 особливістю спеціальності та зі специфікою викладання загальнотехнічної дисципліни, аналіз наявних програмних засобів інформаційно-освітнього середовища 3 метою визначення приблизної структури та змісту комплексу навчальних комп’ютерних інтерактивних тренажерів для підготовки майбутніх інженерів ${ }^{16}$;

2) вибір окремих вагомих термінів та понять, які обов'язково повинні бути вивчені майбутніми інженерами в межах загальнотехнічних дисциплін ${ }^{17,18}$;

3) підготовка теоретичного матеріалу, зокрема у вигляді презентації 3 аудіосупроводом, вебсторінки 3 відеофрагментом, гіпертексту тощо ${ }^{19}$;

4) підготовка тестових завдань для вивчення загальнотехнічної дисципліни, які потребують опанування вищенаведеного матеріалу, 3 використанням різних способів подання інформації ${ }^{20,21}$;

${ }^{15}$ Babenko D., Batsurovska I., Dotsenko N., Gorbenko O., Andriushenko I., Kim N. Application of monitoring of the informational and educational environment in the engineering education system. Modern Electrical and Energy Systems (MEES), Kremenchuk. 2019.

16 Бацуровська I.В., Доценко Н.А., Горбенко О.А., Кім Н.І. Дослідження використання інтерактивних аудіовізуальних онлайн-засобів при підготовці фахівців аграрного профілю в умовах інформаційно-освітнього середовища. Освітній дискурс: збірник наукових праць. 2019. С. 88-104

17 Левина М.М. Технологии профессионального педагогического образования : учебное пособие. Москва : Академия, 2001.

18 Дубасенюк О. А. Професіографічний підхід у підготовці майбутніх магістрів освіти в контексті інформаційно-комунікаційних технологій. Теорія і практика професійної майстерності в умовах цілежиттєвого навчання: монографія. Житомир : Вид-во Рута. 2016. С. 192.

${ }^{19}$ Knepell P. L., Arangno D. C. Simulation Validation: A Confidence Assessment Methodology. Los Alamitos, California. IEEE computer society press monograph. 1993.

20 Uskov V. L. Smart Education and Smart Learning. Springer International Publishing Switzerland. 2015. 
5) розроблення модулю перевірки знань із загальнотехнічної дисципліни у вигляді навчального тренажера 22 .

Під час створення навчальних комп'ютерних інтерактивних тренажерів в умовах інформаційно-освітнього середовища виникає необхідність комбінування різних типів питань та завдань ${ }^{23}$. Так, навчальний комп’ютерний інтерактивний тренажер створює можливість перевірки ступеня засвоєння знань на всіх рівнях. Представлено класифікацію навчальних комп'ютерних інтерактивних тренажерів, які використовуються для підготовки здобувачів вищої освіти в контексті вивчення загальнотехнічних дисциплін (рис. 5).

Виділимо типи навчальних комп'ютерних інтерактивних тренажерів, які можна використовувати для підготовки майбутніх інженерів:

1) електронні тестові навчальні тренажери. У покладено інженерні тестові завдання, які допомагають у засвоєнні правил, методик, законів, теорем та іншого контенту у сфері інженерії (рис. 6). $Є$ сукупністю завдань, розташованих у певному порядку. Такий тренажер дає можливість оцінити знання, навички та набуті компетентності здобувачів вищої освіти. До електронних тестових навчальних тренажерів ми зарахували електронні тестові навчальні тренажери 3 можливістю множинного вибору, 3 можливістю вибору двозначної відповіді, з тестовою короткою відповіддю та числовою відповіддю та тренажер з елементами на обчислення ${ }^{24}$;

2) графічні навчальні тренажери. Вони засновані на тренуванні зорового сприйняття та роботі з інженерними кресленнями, схемами, іншими графічними об'єктами ${ }^{25}$. До графічних навчальних тренажерів належать такі тренувальні завдання, в основу яких покладено роботу 3 інженерно-графічними зображеннями в умовах інформаційноосвітнього середовища. Зображення можна доповнити невеликими порціями тексту (наприклад перетягуванням зображення в текст, тексту

${ }^{21}$ Доценко Н.А. Впровадження елементів STEM освіти під час підготовки бакалаврів 3 агроінженерії в умовах інформаційно-освітнього середовища. Педагогіка формування творчої особистості у вищій та загальноосвітній школах. № 69. С. 181-187.

22 Доценко Н.А. Педагогічний зміст професійної підготовки бакалаврів 3 агроінженерії в умовах інформаційно-освітнього середовища. Освітній дискурс. № 1. 2020. C. 104-116.

${ }^{23}$ Dotsenko N. International scientific conference 'Scientific development of new eastern Europe. System of management of educational process by means of the informational and educational environment. Riga, Latvia, 2019.

24 Доценко Н.А. Методика створення інформаційно-освітнього середовища для професійної підготовки бакалаврів з агроінженерії. Paradigm of knowledge. 2019. C. 87-98.

${ }^{25}$ Oliynik V., Samoylenko O., Batsurovska I., Dotsenko N. Formation of future agricultural engineers professional competencies in computer-oriented environment of higher education institutions. Informational technologies and learning tools. 2018. C. 140-154. 
на зображення чи зображення на зображення та перетягуванням маркерів). При формуванні графічного навчального тренажера формується вибір відповідності тексту й зображення ${ }^{26}$. Якщо неправильно сформовано технологічні зони або не завантажено зображення, то система інформаційно-освітнього середовища про це повідомляє (рис. 7). До таких тренажерів можна зарахувати навчальний тренажер на перетягування графічного зображення в текстове поле, орієнтований на роботу з графічними маркерами, та на перетягування тексту на графічне зображення і зображення на зображення;

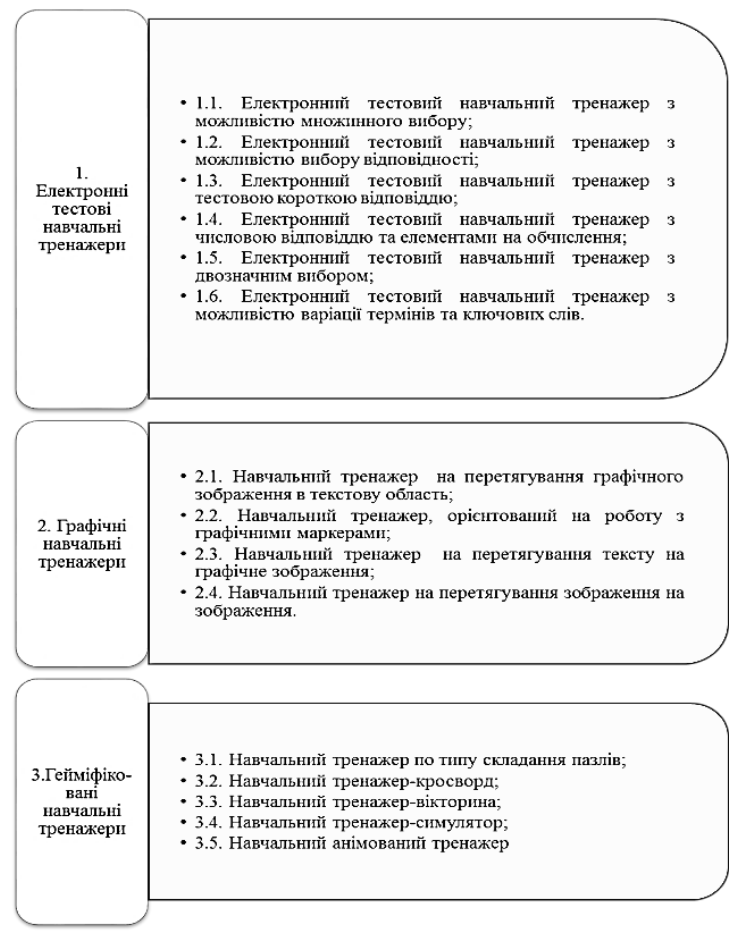

Рис. 5. Класифікація навчальних комп'ютерних інтерактивних тренажерів у системі викладання загальнотехнічних дисциплін

26 Доценко Н.А. Використання навчальних комп'ютерних інтерактивних тренажерів для формування фахових компетентностей в професійній підготовці бакалаврів 3 агроінженерії в умовах інформаційно-освітнього середовища. Вісник Черкаського наиіонального університету імені Богдана Хмельнищького. Серія: педагогічні науки. 2020. С. 124-129. 

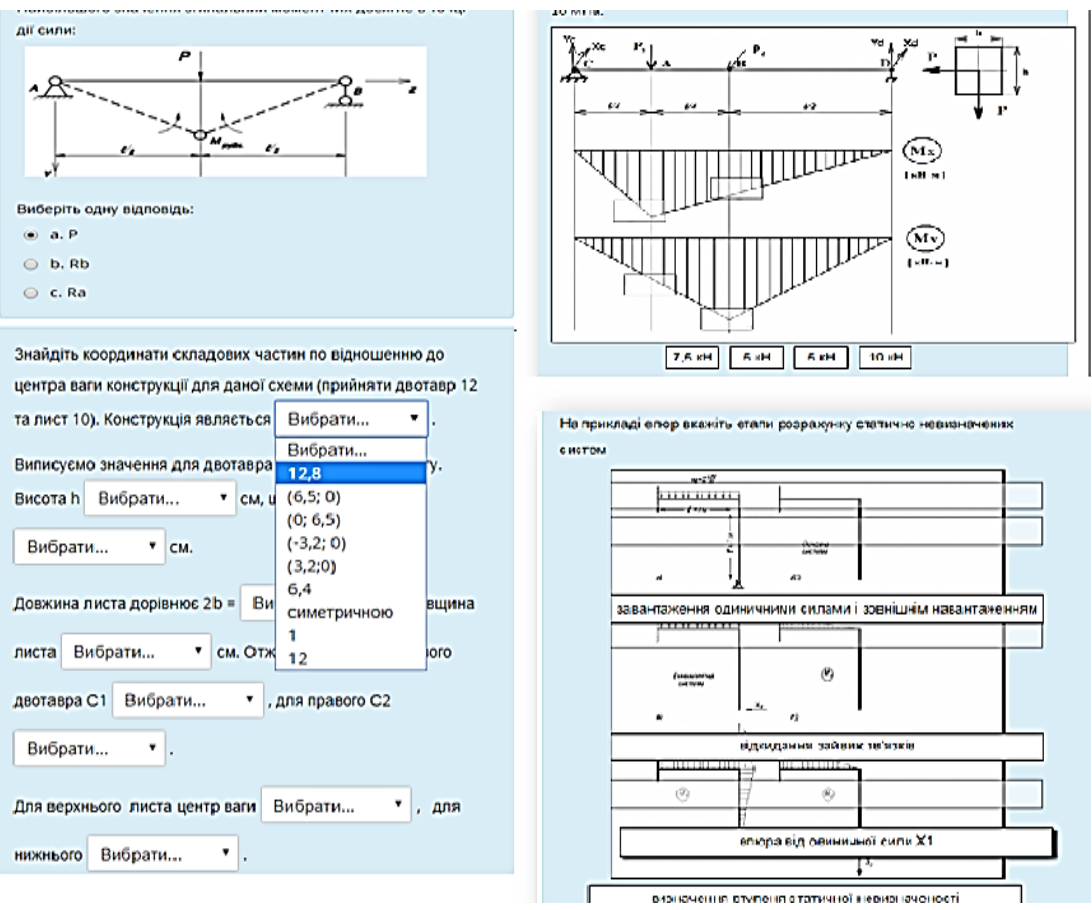

Рис. 6. Інтерактивні тестові навчальні тренажери для вивчення загальнотехнічних дисциплін

3) гейміфіковані навчальні тренажери. До них зараховують тренажери, в основу яких покладено виконання завдань в ігровій формі в умовах інформаційно-освітнього середовища. Гейміфікація бере за основу використання ігрових підходів в умовах інформаційноосвітнього середовища. До них належить знайомство 3 деталями та пристроями, що закладені в основу інженерії, з принципами навчання експлуатації складної аграрної техніки; навички монтажу, збирання систем, а також пошук несправностей та ремонт техніки. До таких тренажерів можна віднести навчальний тренажер за типом складання пазлів, тренажер-кросворд, тренажер-вікторину та тренажер на складання схем та інженерних процесів у режимі онлайн. Розглянемо їх педагогічні характеристики. Представимо методику створення та можливості окреслених тренажерів для бакалаврів інженерних спеціальностей (рис. 8). 


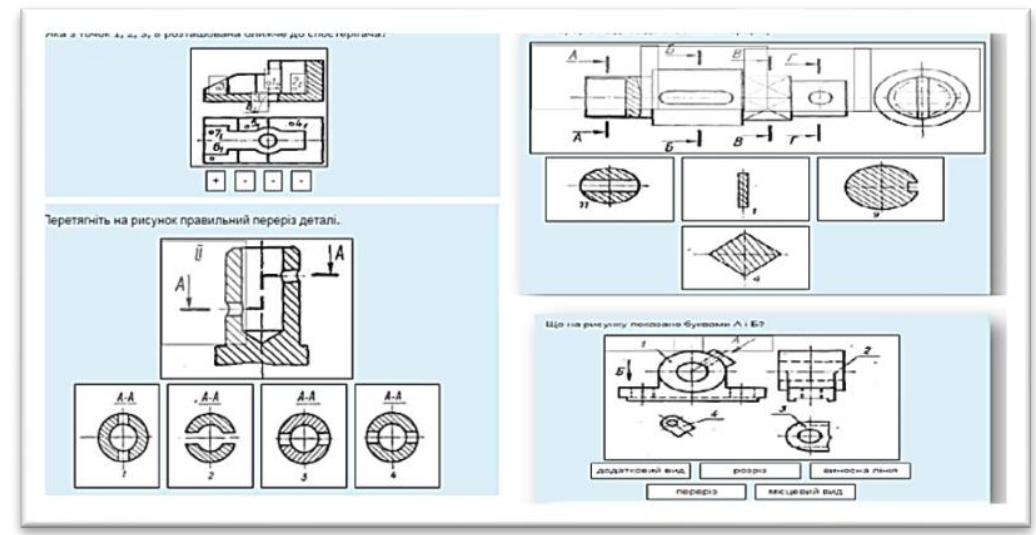

Рис. 7. Графічні навчальні тренажери для опанування загальнотехнічних дисциплін
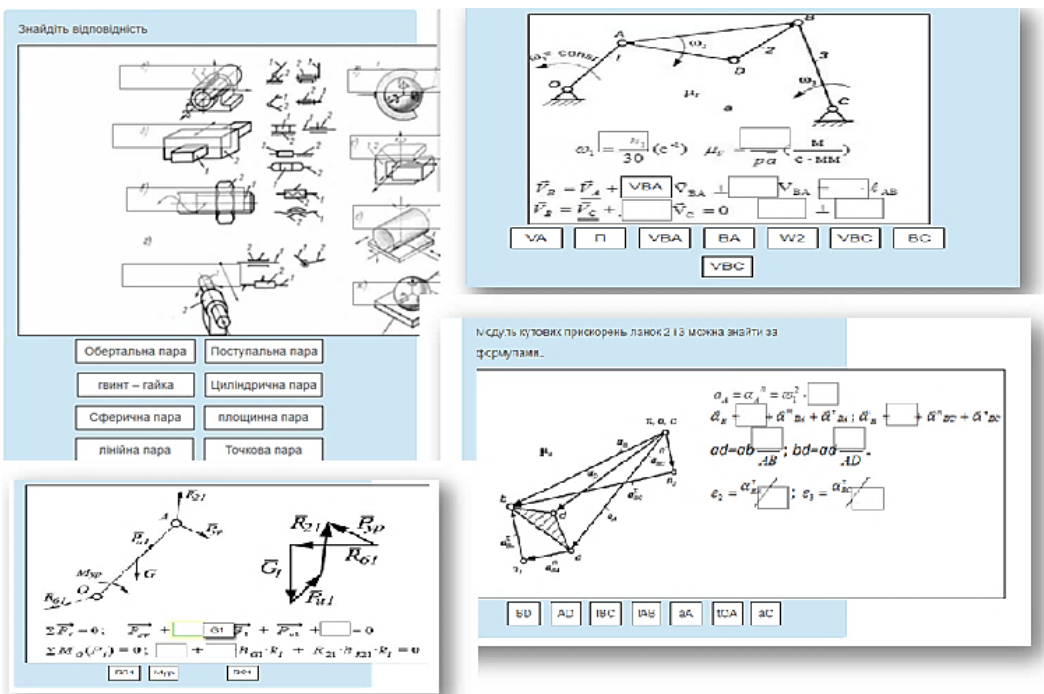

Рис. 8. Інтерактивні навчальні комп'ютерні тренажери для вивчення загальнотехнічних дисциплін

Ефективне застосування навчальних тренажерів в освітньому процесі дозволяє значно зменшити кількість помилок, збільшити швидкість маніпуляції й ухвалення рішень, скоротити час навчання, більш адекватно 
оцінювати рівень отриманих знань і набутих навичок, індивідуалізувати навчання, формувати висновки щодо дій майбутніх фахівців.

Імплементація навчальних тренажерів у інформаційно-освітне середовище відбувається за рахунок закріплення знань, отриманих у цьому середовищі за допомогою відеолекцій, пояснень до практичних занять у вигляді презентацій з аудіосупроводом, інтерактивних завдань тощо.

В умовах інформаційно-освітнього середовища для створення навчальних комп'ютерних інтерактивних тренажерів $є$ більше 16 типів питань для задоволення навчальних потреб здобувачів вищої освіти інженерних спеціальностей (рис. 9).

До них належать такі: множинний вибір, правильно/неправильно, коротка відповідь, числова відповідь, розрахункова відповідь, есе, на відповідність, випадкове питання на відповідність, вкладені відповіді, вибір пропущених слів, множинна розрахункова відповідь, перетягування в текст, перетягування маркерів, перетягнути на зображення, проста розрахункова відповідь.

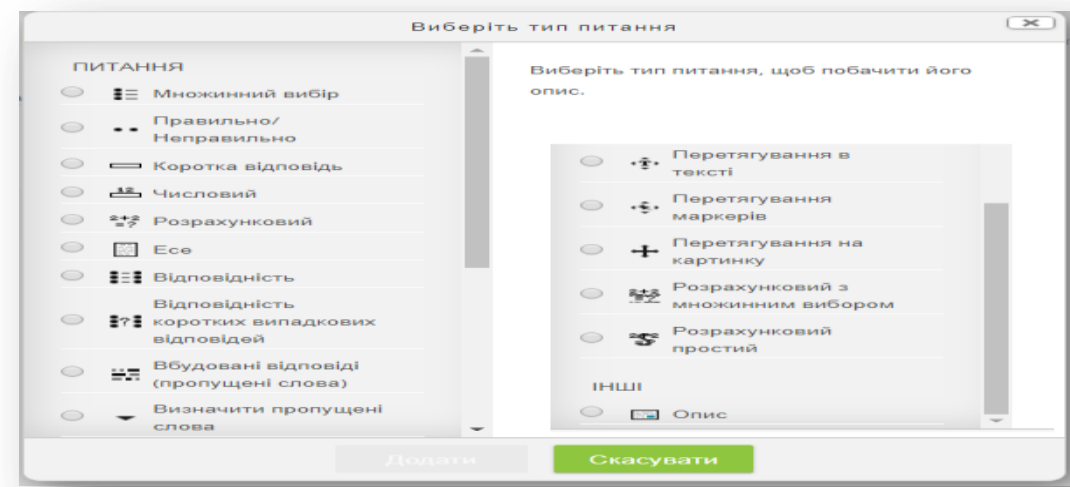

\section{Рис. 9. Типи питань для створення навчальних комп'ютерних інтерактивних тренажерів}

В основу завдань для поточного й модульного контролю при вивченні загальнотехнічних дисциплін покладено різновиди навчальних тренажерів в умовах інформаційно-освітнього середовища. В основу електронних тестових навчальних тренажерів покладено інженерні тестові завдання, які допомагають у засвоєнні правил, методик, законів, теорем та іншого контенту у сфері інженерії. Графічні навчальні тренажери засновані на тренуванні зорового сприйняття та роботі 3 інженерними кресленнями, схемами, іншими графічними об'єктами. 
Гейміфіковані навчальні тренажери мають в основі ігрове завдання, виконання якого розвиває професійні інженерні компетентності. Окреслені типи навчальних комп'ютерних інтерактивних тренажерів розширюють можливості надання освітніх послуг, підкреслюють розмаїття навчального матеріалу із загальнотехнічних дисциплін.

\section{ВИСНОВКИ}

Реалізація шляхів використання цифрового середовища закладу вищої освіти під час викладання загальнотехнічних дисциплін передбачає інтеграцію навчання в аудиторії та віртуальному єдиному просторі. Для підготовки майбутніх інженерів доцільно формувати сучасні електронні інтерактивні посібники із загальнотехнічних дисциплін в умовах цифрового середовища закладу вищої освіти. Такі посібники $є$ допомогою в опануванні як теоретичного матеріалу, так $\mathrm{i}$ навігації курсом, де представлено інтерактивні електронні навчальні інструменти для виконання завдань в умовах цифрового середовища. Такі завдання здобувачі вищої освіти виконують безпосередньо в аудиторії за допомогою гаджетів або персональних комп'ютерів. Окреслений підхід здатен допомогти в якісному опануванні навчального контенту із загальнотехнічних дисциплін, використання інтерактивних електронних навчальних інструментів дозволяє наочно ознайомитися 3 теоретичними, практичними та експериментальними положеннями, що $€$ важливим для вивчення загальнотехнічних дисциплін здобувачами вищої освіти інженерних спеціальностей.

\section{АНОТАЦІЯ}

Розглянуто технологію викладання загальнотехнічних дисциплін у закладах вищої освіти в умовах змішаного навчання. Обгрунтовано доцільність використання навчальних посібників із загальнотехнічних дисциплін для навчання в умовах інформаційно-освітнього середовища закладу вищої освіти. Окреслений підхід здатен допомогти в якісному опануванні навчального контенту із загальнотехнічних дисциплін. Використання інтерактивних електронних навчальних інструментів дозволяє наочно ознайомитися 3 теоретичними, практичними та експериментальними положеннями, що $є$ важливим для підготовки здобувачів вищої освіти інженерних спеціальностей у контексті вивчення загальнотехнічних дисциплін. За допомогою QR-кодів, представлених у навчальних посібниках із загальнотехнічних дисциплін, здобувачі вищої освіти переходять до інтерактивних електронних навчальних інструментів, які є допомогою в опануванні теоретичного матеріалу та навігації курсом в умовах цифрового середовища. Представлено загальний вигляд відтворення інтерактивних електронних навчальних інструментів в умовах інформаційно-освітнього середовища закладу вищої освіти та в 
навчальному посібнику 3 використанням окресленого середовища. Зазначено, що після виконання завдань в умовах інформаційноосвітнього середовища закладу вищої освіти формується рейтинг кожного здобувача, який впливає на підсумкову оцінку.

\section{ЛІТЕРАТУРА}

1. Силадій I.M. Демократизація освіти як свобода вибору моделі освітнього процесу. Національний педагогічний університет імені М.П. Драгоманова. Філософія. № 38(51). 2017. С. 235-241.

2. Decree of the President of Ukraine. 2013.

3. Кухаренко В., Березенська С., Бугайчук К., Олійник Н., Олійник Т., Рибалко О., Столяревська А. Теорія і практика змішаного навчання: монографія. Харків: Міськдрук, НТУ «ХПІ». 2016. С. 286.

4. Agricultural engineers. 2020. URL: https://collegegrad.com/careers/ agricultural-engineers.

5. Benson R., Brack C. Online Learning and Assessment in Higher Education. A Planning Guide. Elsevier. 2010.

6. Cristopner P. 7 Best Praktikes For Developing Personalized elearning Courses. 2016. Available: https://elearningindustry.com/bestpractices-developing-personalized-elearning-courses. (дата звернення: 0305 2018).

7. Wang C.-H., Shannon D. M., Ross M. E. Students' characteristics, self-regulated learning, technology self-efficacy, and course outcomes in online learning. Distance Education. № 34. 2013. C. 302-323.

8. Андрощук I.M. E-learning як ефективна форма самоуправління професійним розвитком викладачів кафедр менеджменту польських закладів вищої освіти. Нова педагогічна думка: науково-методичний журнал. 2018. С. 3-6.

9. Pandey A. 10 Mobile Learning Trends For 2018. Eidesign. 2018.

10. Ткачук C.I. Компетентнісний підхід як основа професійної підготовки інженерів-педагогів харчового профілю у вищих педагогічних навчальних закладах. Сучасні інформаційні технології та інновачійні методики навчання в підготовщі фахівців: методологія, теорія, досвід, проблеми. № 50. 2019. С. 384-387.

11. Шполянская И., Мисиченко Н. Анализ требований работодателей в системе поддержки трудоустройства выпускников ВУЗа. Вестник Государственного ростовского экономического университета «РИНХ». 2009. С. 330-337.

12. Доценко Н.А. Набуття компетенцій в умовах інформаційноосвітнього середовища: організаційний аспект. Освіта $і$ наука в умовах глобальних трансформаиій: матеріали II Всеукраїнської наукової конференції. Дніпро, 2018. 
13. Витвицкая С. Структура и критерии готовности магистров. Вектор науки Тольяттинского Государственного Университета: Серия: Педагогика, психология. № 2 (13). 2013. С. 59-63.

14. Пастухов В. И. Современные требования к квалификации инженера сельскохозяйственного производства. Вісник Українського відділення Міжнародної академії аграрної освіти. Запоріжжя, 2013.

15. Babenko D., Batsurovska I., Dotsenko N., Gorbenko O., Andriushenko I., Kim N. Application of monitoring of the informational and educational environment in the engineering education system. Modern Electrical and Energy Systems (MEES), Kremenchuk. 2019.

16. Бацуровська I.В., Доценко Н.А., Горбенко О.А., Кім Н.I. Дослідження використання інтерактивних аудіовізуальнх онлайнзасобів при підготовці фахівців аграрного профілю в умовах інформаційно-освітнього середовища. Освітній дискурс: збірник наукових праць. 2019. С. 88-104.

17. Левина М.М. Технологии профессионального педагогического образования : учеб. пособие. Москва : Академия, 2001.

18. Дубасенюк О.А. Професіографічний підхід у підготовці майбутніх магістрів освіти в контексті інформаційно-комунікаційних технологій. Теорія і практика професійної майстерності в умовах иілежиттєвого навчання: монографія. Житомир: Вид-во Рута. 2016. C. 192.

19. Knepell P. L., Arangno D. C. Simulation Validation: A Confidence Assessment Methodology. Los Alamitos, California: IEEE computer society press monograph. 1993.

20. Uskov V. L. Smart Education and Smart Learning. Springer International Publishing Switzerland. 2015.

21. Доценко Н.А. Впровадження елементів STEM освіти під час підготовки бакалаврів 3 агроінженерії в умовах інформаційноосвітнього середовища. Педагогіка формування творчої особистості у вищій та загальноосвітній школах. № 69. С. 181-187.

22. Доценко Н.А. Педагогічний зміст професійної підготовки бакалаврів 3 агроінженерії в умовах інформаційно-освітнього середовища. Освітній дискурс. № 1. 2020. С. 104-116.

23. Dotsenko N. International scientific conference 'Scientific development of new eastern Europe. System of management of educational process by means of the informational and educational environment. Riga, Latvia, 2019.

24. Доценко Н.А. Методика створення інформаційно-освітнього середовища для професійної підготовки бакалаврів 3 агроінженерії. Paradigm of knowledge. 2019. С. 87-98.

25. Oliynik V., Samoylenko O., Batsurovska I., Dotsenko N. Formation of future agricultural engineers professional competencies in computer- 
oriented environment of higher education institutions. Informational technologies and learning tools. 2018. C. 140-154.

26. Доценко Н. А. Використання навчальних комп'ютерних інтерактивних тренажерів для формування фахових компетентностей в професійній підготовці бакалаврів 3 агроінженерії в умовах інформаційно-освітнього середовища. Вісник Черкаського начіонального університету імені Богдана Хмельницького. Серія: педагогічні науки. 2020. С. 124-129.

\section{Information about the author:} Dotsenko N. A.,

Doctor of Pedagogical Sciences, Associate Professor, Associate Professor at the Department of General Technical Disciplines Mykolayiv National Agrarian University 9, Heorhiia Honhadze str., Mykolayiv, 54000, Ukraine 